\title{
PENGARUH KOMUNIKASI ORGANISASI TERHADAP KEPUASAN KERJA KARYAWAN DI PD BPR LPK GARUT KOTA CABANG BAYONGBONG
}

\author{
Yeni Andriyani \\ Iis Dewi Fitriani \\ STIE Muhammadiyah Bandung \\ Jl. Karapitan No.143 Bandung
}

\begin{abstract}
Abstrak
Terciptanya komunikasi organisasi di dalam perusahaan dapat dikatakan baik apabila tercapainya pemahaman antara para pengirim dan penerima. Dengan komunikasi yang efektif para karyawan dapat bekerja dengan baik dan timbulnya kepuasan kerja atas hasil yang dikerjakannya, karena merasa telah dibekali oleh informasi yang jelas dan akurat. Sebaliknya pemimpin juga dapat mengetahui sejauh mana karyawannya dapat mengerti akan tugas-tugasnya dan sejauh mana perhatian karyawan terhadap perusahaan maupun pada atasannya.

Dalam penelitian ini penulis menggunakan metode deskriptif denganmengumpulkan data yang sesuai dengan keadaan yang sebenarnya, menyajikan serta menganalisa sehingga dapat memberikan gambaran yang cukup jelas atas objek yang diteliti dan kemudian dapat ditarik kesimpulan untuk menggambarkan, menjelaskan keadaan yang ada di perusahaan berdasarkan faktor dan data yang dikumpulkan kemudian disusun secara sistematis.

Dari rekapitulasi hasil pengujian validitas dan reliabilitas instrumen untuk variabel kepuasan kerja karyawan terlihat bahwa seluruh pernyataan yang diajukan memiliki koefisien validitas di atas titik kritis 0,300. Hal ini menunjukan bahwa seluruh pernyataan yang diajukan tersebut sudah melakukan fungsi ukurnya. Dan dari hasil pengujian reliabilitas instrumen, diperoleh nilai koefisien alpha sebesar 0,844. Nilai ini lebih besar dari 0,600 yang menunjukan bahwa variabel kepuasan kerja karyawan sudah menunjukan keandalannya.

Komunikasi organisasi berpengaruh positif dan signifikan terhadap kepuasan kerja karyawan PD. BPR LPK Garut Kota Cabang Bayongbong dengan kontribusi pengaruh yang diberikan sebesar $28,7 \%$, sedangkan sisanya sebesar $71,3 \%$ merupakan kontribusi dari faktor lain yang tidak diteliti, Berdasarkan kajian teoritis, variabel lain diluar variabel yang diteliti yang mempengaruhi kepuasan kerja adalah: kinerja karyawan, Motivasi, kompensasi, efektivitas kepemimpinan, budaya organisasi, dan stress kerja.
\end{abstract}

Kata kunci : Komunikasi Organisasi dan Kepuasan Kerja 


\section{PENDAHULUAN}

Manusia merupakan unsur yang terpenting dalam suatu organisasi, maka pemeliharaan hubungan yang terus-menerus dan serasi antara pimpinan dengan bawahan dalam setiap organisasi menjadi sangat penting. Pemeliharaan hubungan tersebut adalah menyangkut komunikasi organisasi agar tercapai kepuasan kerja karyawan.

Dalam perkembangan yang pesat di bidang pendidikan, ekonomi, industri, teknologi dan globalisasi sangat dituntut kemajuannya, sehingga dapat selaras dan seimbang dengan dinamika zaman saat ini. Salah satu yang mendukung untuk kemajuan tersebut dibutuhkan keterampilan komunikasi di mana kemampuan komunikasi menunjukkan keberhasilan seseorang dalam mengirim informasi atau pesan secara jelas, manusiawi dan efisien. Disamping itu juga komunikasi memiliki nilai-nilai sarana informasi, motivasi juga mengekspresikan emosi dan dapat mempengaruhi orang lain dalam mewujudkan suatu perkembangan dan kemajuan perusahaan kedepan yang lebih baik.

Penting bagi pemimpin untuk mengusahakan terciptanya komunikasi organisasi. Sebab dengan komunikasi organisasi akan tercipta peningkatan kepuasan kerja karyawan. Karena karyawan di satu pihak selalu megharapkan perhatian akan kebutuhan dan keinginan mereka, dan mereka juga mempunyai kewajiban untuk melaksanakan tugas-tugas yang telah dibebankan dan dituntut agar dilaksanakan dengan baik.

PD BPR LPK merupakan perusahaan daerah bank perkreditan rakyat yang kepemilikannya bersama antara Pemerintah Kabupaten Garut,
Pemerintah Provinsi Jawa Barat dan PT.Bank Jabar.

Kegiatan usaha dari PD BPR LPK Garut Kota Cabang Bayongbong meliputi usaha menghimpun dana dari masyarakat berupa tabungan dan deposito berjangka serta memberikan kredit. Selain itu perusahaan tersebut juga melakukan pembinaan khususnya kepada pengusaha golongan ekonomi lemah dan melakukan kerjasama dengan Lembaga Perbankan atau Lembaga Keuangan non bank serta menjalankan usaha-usaha perbankan lainnya sepanjang tidak bertentangan dengan perundangan-undangan yang berlaku.

Peneliti melakukan wawancara pendahuluan pada beberapa karyawan yang ada diperusahaan PD BPR LPK Garut Kota Cabang Bayongbong, bahwa dalam komunikasi organisasi sering terjadi penyampaian informasi yang kurang baik, hal ini sering terjadi dari pernyataan yang terdengar diantara para anggota organisasi bahwa "Kami sama sekali tidak mengerti mengenai apa yang sebenarnya terjadi." Keluhan semacam itu menunjukkan bahwa komunikasi dalam organisasi itu tidak berjalan dengan baik. Hal tersebut tidak akan terjadi jika sumber daya manusia didalam organisasi dapat menjalin komunikasi yang baik, sehingga apa yang di instruksikan oleh atasan dapat di mengerti dan di lakukan oleh bawahan. Karena komunikasi organisasi adalah pengiriman dan penerimaan informasi dalam organisasi yang kompleks. Komunikasi organisasi ini antara lain, hubungan antar manusia, komunikasi dari atasan kepada bawahan, seperti : komunikasi dari bawahan kepada atasan, komunikasi dengan sesama rekan kerja, keterampilan berkomunikasi dan 
berbicara,

mendengarkan, menulis,Redding and Saborn (1978) (Dalam Muhammad,2014:90). Dengan adanya kejadian diatas dapat menimbulkan ketidakpuasankerja karyawan. Karena Kepuasan kerja menurut Coleman (1982) (dalam Muhammad,2014:90) merupakan respons seseorang (sebagai pengaruh) terhadap bermacam-macam kerja yang dihadapinya. Termasuk kedalam hal ini respons terhadap komunikasi organisasi, supervisor, kompensasi, promosi, teman sekerja, kebijaksanaan organisasi dan hubungan interpersonal dalam hubungan organisasi. Selanjutnya Coleman mengatakan bahwa semua variabel komunikasi berhubungan secara berarti dengan aspek kepuasan kerja.

Terciptanya

komunikasi

organisasi di dalam perusahaan dapat dikatakan baik apabila tercapainya pemahaman antara para pengirim dan penerima. Dengan komunikasi yang efektif para karyawan dapat bekerja dengan baik dan timbulnya kepuasan kerja atas hasil yang dikerjakannya, karena merasa telah dibekali oleh informasi yang jelas dan akurat. Sebaliknya pemimpin juga dapat mengetahui sejauh mana karyawannya dapat mengerti akan tugas-tugasnya dan sejauh mana perhatian karyawan terhadap perusahaan maupun pada atasannya.

Sedangkan ketidakpuasan kerja dapat dinyatakan dalam berbagai cara, yaitu berhenti bekerja, pegawai mengeluh, tidak patuh dan mengelakkan sebagian dari tanggung jawab kerjanya, Hasibuan (2007 : 202). Pada tabel 1.1 disajikan data tentang pegawai yang berhenti bekerja dari tahun 2011 sampai 2013.

Tabel 1. Kepuasan Kerja Periode 2011 - 2013

\begin{tabular}{|c|c|c|c|c|c|}
\hline No. & Tahun & $\begin{array}{c}\text { Jumlah } \\
\text { Karyawan Awal } \\
\text { Tahun }\end{array}$ & $\begin{array}{c}\text { Karyawan } \\
\text { Berhenti Bekerja } \\
\text { (Keluar) }\end{array}$ & $\begin{array}{c}\text { Karyawan } \\
\text { Baru (Masuk) }\end{array}$ & $\begin{array}{c}\text { Jumlah } \\
\text { Karyawan Akhir } \\
\text { Tahun }\end{array}$ \\
\hline 1. & 2011 & 34 & 4 & 5 & 35 \\
\hline 2. & 2012 & 35 & 2 & 3 & 36 \\
\hline 3. & $\begin{array}{c}2013 \\
\text { (Jan-Des) }\end{array}$ & 36 & 5 & 5 & 36 \\
\hline
\end{tabular}

Sumber : PD BPR LPK Garut Kota Cabang Bayongbong

Dari table di atas pada tahun 2011 sampai 2013 bisa terlihat jumlah karyawan yang berhenti bekerja sebanyak 11 orang selama 3 (tiga) tahun. Hal ini menunjukkan bahwa adanya penurunan jumlah karyawan yang berpengaruh terhadap kepuasan kerja di PD BPR LPK Garut Kota Cabang Bayongbong.

Berdasarkan uraian di atas, peningkatan kepuasan kerja karyawan sangat penting. Oleh sebab itu perusahaan perlu memperhatikan salah satu faktor yang mempengaruhi kepuasan kerja, yaitu dengan adanya komunikasi organisasi yang baik.

\section{KERANGKA TEORITIS \& HIPOTESIS \\ Kepuasan Kerja}

Kepuasan kerja adalah suatu efektifitas atau respon emosional terhadap aspek pekerjaan. Kepuasan kerja merupakan generalisasi sikap- 
sikap terhadap pekerjaan yang didasarkan atas aspek-aspek pekerjaan. Kepuasan kerja merupakan masalah yang cukup menarik dan penting, baik bagi individu sebagai pekerja maupun bagi perusahaan. Seorang manajer perlu menciptakan lingkungan kerja yang dapat memenuhi kebutuhan atau motif pekerjaannya, guna terciptanya tujuan organisasi sebagaimana yang diharapkan. Berikut ini terdapat beberapa pendapat ahli tentang pengertian kepuasan kerja, yaitu : Menurut Hasibuan (2007 : 202) kepuasan kerja adalah sikap emosional yang menyenangkan dan mencintai pekerjaannya,karena sikap ini mencerminkan oleh moral kerja,kedisiplinan, dan prestasi kerja.

Menurut Robbins,(2001:25). Kepuasan kerja adalah suatu sikap umum terhadap pekerjaan seseorang, selisih antara banyaknya ganjaran yang diterima seorang pekerja dan banyaknya yang mereka yakini seharusnya mereka terima.

Sedangkan menurut Coleman (1982) (Dalam Muhammad,2014:90) :

"Kepuasan kerja merupakan respons seseorang (sebagai pengaruh) terhadap bermacam-macam kerja yang dihadapinya. Termasuk kedalam hal ini respons terhadap komunikasi organisasi, supervisor, kompensasi, promosi, temen sekerja, kebijaksanaan organisasi dan hubungan interpersonal dalam hubungan organisasi".

Menurut Sondang P.Siagian (2008:295) menyatakan bahwa kepuasan kerja adalah suatu cara pandang seseorang baik yang bersifat positif maupun bersifat negatif tentang pekerjaannya. \begin{tabular}{lrr}
\multicolumn{2}{c}{ Menurut Danang } & Sunyoto \\
$(2013: 15) \quad$ kepuasan kerja & adalah \\
keadaan & emosional & yang \\
menyenangkan $\quad$ atau & tidak
\end{tabular} menyenagkan dimana para karyawan memandangkan pekerjaannya.

Menurut Locke (Fred Luthans, 2006:243) mengemukakan bahwa kepuasan kerja merupakan keadaan emosi yang senang atau emosi tidak senang yang berasal dari penilaian pekerjaan atau pengalam kerja seseorang.

Dari beberapa definisi tersebut dapat diambil kesimpulan bahwa kepuasan kerja merupakan derajat perasaan seseorang, baik positif maupun negatif terhadap pekerjaannya. Kepuasan kerja menunjukkan sikap berdasarkan penilaian pekerjaan terhadap berbagai aspek dari tugastugas, situasi kerja, serta hubungan antar pekerja. Kepuasan kerja mempunyai pengaruh yang cukup besar terhadap produktifitas suatu organisasi baik secara langsung maupun tidak langsung. Ketidakpuasan merupakan titik awal dari munculnya masalahmasalah dalam organisasi.

\section{Faktor-faktor kepuasan kerja karyawan}

Menurut As'ad (2003:114) Faktorfaktor yang mempengaruhi kepuasan kerja karyawan adalah sebagai berikut:

1. Kesempatan untuk maju yaitu ada tidaknya kesempatan untuk memperoleh pengalaman dan peningkatan kemampuan selama kerja.

2. Keamanan yaitu sebagai a baik bagi penunjang kepuasan kerja baik bagi karyawan pria mapun wanita.

3. Gaji yaitu lebih banyak menyebabkan ketidakpuasan kerja dan jarang orang mengeksprisikan 
kepuasan kerjanya dengan sejumlah uang yang diperolehnya.

4. Perusahaan dan manajemen yang baik adalah yang mampu memberikan situasi dan kondisi kerja yang stabil.

5. Pengawasan atau supervisi, bagi karyawan, supervisor dianggap sebagai figur ayah sekaligus atasannya. Supervisi yang buruk dapat menaikkan tingkat kemangkiran dan perputaran pegawai.

6. Faktor intrinsik dari pekerjaan, atribut yang ada pada pekerjaan mensyaratkan keterampilan tertentu.

7. Kondisi kerja, termasuk kondisi tempat, ventilasi, kantin serta tempat parkir.

8. Aspek social dalam pekerjaan, merupakan salah satu sikap sulit digambarkan tetapi dipandang sebagai faktor penunjang kepuasan kerja.

9. Komunikasi, antara karyawan dengan pihak manajemen banyak dipakai alasan untuk menyukai jabatannya. Dalam hal ini adanya kesediaan pihak atasan untuk mau mendengar, memahami dan mengakui pendapat atau prestasi para karyawan sangat berperan dalam menimbulkan rasa puas terhadap kerja.

Menurut Hasibuan (2007 : 203) ada empat faktor yang digunakan dalam mencapai kepuasan kerja karyawan dalam suatu organisasi perusahaan. Keempat faktor tersebut seperti, Berhenti bekerja ,Pegawai mengeluh,Tidak patuh,Mengelakkan sebagian dari tanggung jawab kerjanya Sedangkan menurut Robbins (2001:149)mengemukakan faktor- faktor yangmendorong kepuasan kerja. Faktor-faktor tersebut adalah

1. Kerja yang menantang

Karyawan cenderung lebih menyukai pekerjaan-pekerjaan yang memberikan mereka kesempatan untuk menggunakan keterampilan dan kemampuan mereka dan menawarkan beragam tugas, kebebasan, dan umpan balik mengenai betapa baik mereka bekerja. Pekerjaan yang kurang menantang menciptakan kebosanan, tetapi yang terlalu banyak menantang menciptakan frustasi dan perasan gagal. Pada kondisi tantangan yang sedang, kebanyakan karyawan akan mengalami kesenangan dan kepuasan.

2. Ganjaran yang pantas

Ganjaran yang pantas merupakan salah satu bentuk imbalan yang diberikan oleh pihak kantor atas beban kerja yang diberikan kepada seorang pekerja.

3. Rekan sekerja yang mendukung

Terdapat dua bentuk yang terjadi diantara rekan sekerja yaitu interaksi yang sehubungan dengan pekerjaan dan hubungan yang terjadi diluar jam kerja tetapi tidak ada hubungan dengan aktivitas kerja. Memiliki rekan kerja yang dapat memenuhi kebutuhan, baik dalam kepentingan untuk saling bekerjasama dalam bekerja maupun kebutuhan untuk saling memiliki dan menghargai merupakan salah satu sumber dari kepuasan kerja.

4. Kondisi kerja

Kondisi kerja yang dimaksud disini adalah mengenai kondisi fisik, jumlah jam kerja, dan fasilitas yang memandai untuk melakukan pekerjaan. Kondisi fisik yang 
membuat nyaman seperti suhu ruangan, jumlah jam kerja yang pasti dan sesuai dengan kemampuan fisik seorang pekerja, serta fasilitas sarana prasarana yang menunjang seorang pegawai untuk bekerja merupakan salah satu sumber kepuasan seseorang dalam bekerja.

Berkaitan dengan penelitian, yang dijadikan alat ukur dari kepuasan kerja sebagai variabel Y dalam penelitian ini adalah faktor-faktor di atas.

\section{Analisis tentang kepuasan kerja}

Pemahaman yang lebih tepat tentang kepuasan kerja dapat terwujud apabila analisis tentang kepuasan kerja dengan Kedisiplinan, Umur Karyawan, Organisai,

(Hasibuan,2007 : 203)

1. Kepuasan Kerja dan Kedisiplinan Kepuasan kerja mempengaruhi tingkat kedisiplinan karyawan, artinya kepuasan diperoleh dari pekerjaan maka kedisiplinan karyawan baik. Sebaliknya jika kepuasan kerja kurang tercapai dari pekerjaannya maka kedisiplinan karyawan rendah.

2. Kepuasan Kerja dan Umur Karyawan

Umur karyawan mempengaruhi kepuasan kerja. Karyawan yang masih muda, tuntutan kepuasan kerjanya tinggi, sedangkan karyawan tua tuntutan kepuaan kerjanya relatif rendah.

3. Kepuasan Kerja dan Organisasi

Besar-kecilnya organisasi mempengaruhi kepuasan kerja karyawan. Semakin besar organisasi, kepuasan kerja karyawan semakin menurun karena peranan mereka semakin kecil dalam mewujudkan tujuan. Pada organisasi yang kecil kepuasan kerja akan semakin besar karena peranan mereka semakin besar dalam wujudkan tujuan.

4. Kepuasan Kerja dan Kepemimpinan

Kepuasan kerja karyawan banyak dipengaruhi sikap pemimpin dalam kepemimpinannya. Kepemimpinan partisipasi memberikan kepuasan kerja bagi karyawan karena karyawan ikut aktif dalam memberikan pendapatnya untuk menentukan kebijaksanaan perusahaan. Kepemimpinan otoriter mengakibatkan kepuasan kerja karyawan rendah.

Maka dari itu bahwa kepuasan kerja karyawan merupakan kunci pendorong moral, kedisiplinan, dan prestasi kerja karyawan dalam mendukung terwujudnya tujuan perusahaan.

\section{Komunikasi Organisasi}

Komunikasi dalam organisasi memegang peranan sangat penting dalam menunjang aktivitas organisasi. Setiap fungsi manajemen sumber daya manusia selalui disertai komunikasi, dimulai dari proses seleksi, wawancara sampai pemutusan hubungan kerja semuanya membutuhkan komunikasi. komunikasi organisasi merupakan hal yang penting didalam kehidupan berorganisasi sehingga diperlukan beberapa pemahaman mengenai komunikasi organisasi.

Maka dari itu ada beberapa pengertian komunikasi organisasi oleh para ahli antara lain yaitu :

Menurut Redding and Saborn

(1978) (Dalam Muhammad,2014:66)

"komunikasi organisasi adalah pengiriman dan penerimaan informasi dalam organisasi 
yang kompleks. Komunikasi organisasi ini antara lain, hubungan antar manusia, komunikasi dari atasan kepada bawahan, seperti : komunikasi dari bawahan kepada atasan, komunikasi dengan sesama rekan kerja, keterampilan berkomunikasi dan berbicara mendengarkan, menulis".

Menurut Katz dan Kahn (1978)(Dalam Muhammad,2014:66) "Bahwa komunikasi organisasi merupakan arus informasi, pertukaran informasi dan pemindahan arti didalam suatu organisasi"

Menurut Thayer (1986) bahwa komunikasi organisasi sebagai arus data komunikasi yang akan melayani komunikasi organisasi dan proses interkomunikasi dalam beberapa cara, seperti :

a. Berkenaan dengan kerja organisasi

b. Berkenaan dengan pengaturan organisasi

c. Berkenaan pemeliharaan

dengan perkembangan organisasi.

Menurut Zelko dan Dance (1975) (Dalam Muhammad,2014:66) "Komunikasi organisasi adalah suatu sistem yang saling tergantung yang mencakup komunikasi internal dan eksternal"

Berdasarkan pendapat para ahli di atas dapat diketahui bahwa komunikasi organisasi merupakan suatu sistem terbuka yang kompleks yang dipengaruhi oleh lingkungannya sendiri baik internal maupun eksternal, meliputi pesan dan arusnya, tujuan, arah dan media. Juga meliputi orang dan sikapnya, perasaannya, hubungannya, dan keterampilannya dalam menyampaikan informasi.

Faktor-faktor

Komunikasi Organisasi

Menurut Denis (1975) (Dalam Muhammad,2014:86) mengemukakan empat faktor komunikasi organisasi yaitu: Supportiveness partisipasi; Pembuatan keputusan; Keterbukaan dan keterus-terangan; Tujuan penampilan yang tinggi.

Sedangkan menurut Robert dan

O'Realy (1987) (Dalam Muhammad,2014:87) mengembangkan suatu faktor-faktor suatu pengukuran komunikasi organisasi yang dirancang untuk mengukur 15 area komunikasi organisasi seperti: kebenaran, pengaruh, mobilitas, keinginan berinteraksi, pengarahan dari atasan, dari bawahan, pengarahan yang lateral, ketelitian, peringkasan, penyimpanan, kelebihan beban, rasa puas, berkenaan dengan tulisan, tatap muka dan percakapan melalui telepon.

\section{Model Komunikasi Organisasi}

Yang dimaksud dengan model komunikas adalah gambaran yang sederhana dari proses komunikasi yang memperlihatkan kaitan antara satu komponen komunikasi dengan komponen lainnya. Penyajian model ini dimaksudkan untuk mempermudah memahami proses komunikasi dan melihat komponen dasar yang ada dalam suatu komunikasi, (muhammad, 2014:5).

\section{Model $\mathrm{S}-\mathrm{R}$}

Model stimulus - respons ( $\mathrm{S}$ R) adalah model komunikasi paling dasar. Model ini dipengaruhi oleh disiplin psikologis, khususnya yang beraliran behavioristik. Model 
ini tersebut menggambarkan hubungan stimulus - respons.

Stimulus

Respons

\section{Gambar 1.Model komunikasi}

Sumber : Muhammad, 2014:5

Model ini menunjukkan komunikasi sebagai proses aksi - reaksi yang sangat sederhana. Jadi model $\mathrm{S}-\mathrm{R}$ mengasumsikan bahwa kata-kata verbal (lisan - tulisan), isyarat-isyarat nonverbal, gambar-gambar, dan tindakan-tindakan tertentu akan merangsang orang lain untuk memberikan respons dengan cara tertentu

2. Model lasswell

Dalam model komunikasi Harold Lasswell ini, menggunakan lima pertanyaan yang perlu ditanyakan dan dijawab dalam melihat proses komunikasi, yaitu who (siapa), says what (mengatakan apa), in which medium (menggunakan media apa), to whom (kepada siapa), dan what effect (apa

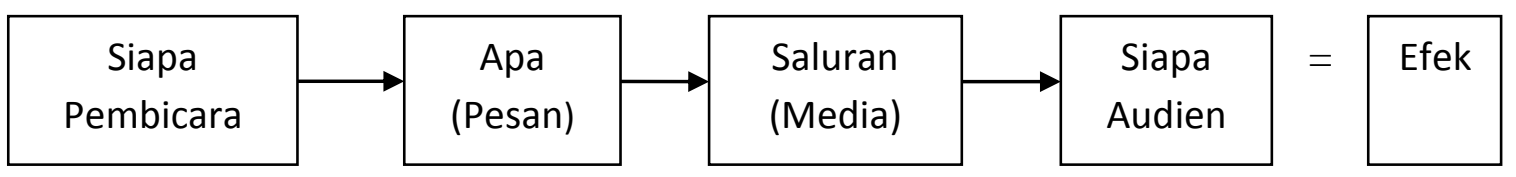

Gambar 2. Proses komunikasi

Sumber : Muhammad, 2014:6

Dalam komunikasi biasanya terlihat adanya faktor sumber gangguan pada waktu memindahkan signal dari komunikator kepada komunikan. Misalnya pada waktu berbicara dijalan terdengar suara mobil dan mengganggu pembicaraan, itu dinamakan noise.

Untuk menetralkan gangguan ini Shannon (dalam Muhammad,2014:17) mengemukakan empat cara yaitu:

1. Menambahkan kekuatan atau power dari signal. Misalnya memperkeras suara kita ketika berbicara dijalan karena suasana yang ramai.

2. Mengarahkan signal dengan persis. Berbicara lebih dekat dengan penerima agar terdengar lebih jelas.

3. Menggunakan signal lain. Maksud dari signal lain disini adalah dengan gerakan kepala, gerakan badan dan lain-lain.

4. Redudansi. Redudansi dalam situasi yang normal kurang baik digunakan. Tetapi bila terdapat banyak gangguan pengulangan kata-kata kunci sangat diperlukan untuk menjelaskan pesan yang disampaikan.

\section{Komponen Komunikasi Organisasi}

Menurut Muhammad,(2014:17)

Secara teknis dapat dilakukan bahwa komunikasi organisasi melibatkan :

1. Pengirim pesan atau komunikator

Pengirim pesan adalah individu atau orang yang mengirim pesan. Pesan atau informasi yang akan dikirimkan berasal dari otak si pengirim pesan. Oleh karena itu sebelum 
pengirim mengirimkan pesan, pengirim harus menciptakan dulu pesan yang akan dikirimkannya.

2. Pesan

Pesan adalah informasi yang akan dikirimkan kepada komunikan. Pesan ini dapat berupa pesan verbal atau non verbal. Pesan verbal itu bisa lisan dan juga bisa tulisan, sedangkan pesan non verbal bisa berupa gerak tubuh, nada suara, ekspresi muka dan lain lain.

3. Saluran

Saluran adalah jalan yang dilalui pesan dari komunikator dengan komunikan. Channel yang biasa dalam komunikasi adalah gelombang cahaya dan suara yang bisa kita lihat dan dengar, akan tetapi alat yang digunakan itu berbeda-beda.

4. Penerima pesan atau komunikan Penerima pesan adalah yang menganalisis dan menginterprestasikan isi pesan yang di terimanya.

5. Balikan (Feedback)

Balikan adalah respon terhadap pesan yang diterima yang di kirimkan kepada si pengirim pesan atau komunikator. Dengan di berikannya reaksi ini kepada komunikator, komunikator akan dapat mengetahui apakah pesan yang disampikan di interprestasikan sama dengan apa yang dimaksud komunikator.

\section{Gaya Komunikasi Organisasi}

Terdapat dua gaya komunikasi organisasi yang setiap gaya mempunyai pengaruh berbeda terhadap suasana komunikasi. Dua gaya komunikasi organisasi, (Sri Astuti, 2006:19) yaitu:

1. Gaya komunikasi mengendalikan

Gaya komunikasi mengendalikan ditandai dengan adanya satu kehendak atau maksud untuk membatasi, memaksa dan megatur perilaku, pikiran dan tanggapan orang lain. Orang-orang yang menggunakan gaya komunikasi ini dikenal dengan nama komunikator satu arah. Pihak-pihak yang memakai gaya komunikasi ini, lebih memutuskan perhatian kepada pengirim pesan dibanding upaya mereka untuk berharap pesan. Mereka tidak mempunyai rasa ketertarikan dan perhatian pada umpan balik, kecuali jika umpan balik atau feedback tersebut digunakan untuk kepentingan pribadi.

2. Gaya komunikasi dua arah

Gaya komunikasi ini ialah adanya landasan-landasan kesamaan. Gaya komunikasi dua arah ini ditandai dengan berlakunya arus penyebaran pesan-pesan verbal secara lisan maupun tertulis yang bersifat dua arah (two-way communication). Dalam gaya komunikasi ini, tindakan komunikasi dilakukan secara terbuka. Artinya, setiap anggota organisasi dapat mengungkapkan gagasan ataupun pendapat dalam suasana yang rileks, santai dan informal.

Komunikasi dua arah ini akan memudahkan tindak komunikasi dalam organisasi, sebab gaya ini efektif dalam memelihara empati dan kerja sama, khususnya dalam situasi untuk mengambil keputusan terhadap suatu permasalahan yang kompleks.

Hambatan-hambatan Komunikasi Organisasi

Ada tiga hambatan dalam organisasional, yaitu Tingkat Hirarki, Wewenang Manajerial, Spesialisasi.(Sri Astuti, 2006:8) 
1. Tingkat Hirarki

Bila suatu organisasi tumbuh, strukturnya berkembang, akan menimbulkan berbagai masalah komunikasi. Karena berita harus melalui tingkatan (jenjang) tambahan, yang memerlukan waktu yang lebih lama untuk mencapai tempat tujuan dan cenderung menjadi berkurang ketepatannya. Berita yang mengalir ke atas atau kebawah tingkatan-tingkatan organisasi melalui beberapa "filter" , dengan persepsi, motif, kebutuhan dan hubungannya sendiri. Setiap tingkatan dalam rantai komunikasi dapat menambah, mengurangi, merubah, atau sama sekali berbeda dengan berita aslinya.

2. Wewenang Manajerial

Tanpa wewenang untuk membuat keputusan tidak mungkin manajer dapat mencapai tujuan dengan efektif. Tapi dilain pihak, pada kenyataannya bahwa seserorang yang mengendalikan orang lain juga menimbulkan hambatanhambatan terhadap komunikasi. Banyak atasan merasa bahwa mereka tidak dapat sepenuhnya menerima berbagai masalah, kondisi, atau hasil yang dapat membuat mereka tampak lemah. Sebaliknya, banyak bawahan menghindari situasi dimana mereka harus mengungkapkan informasi yang dapat membuat mereka dalam kedudukan yang tidak menguntungkan. Hasilnya ada kesenjangan "leveling" antara atasan dan bawahan.

3. Spesialisasi

Meskipun spesialisasi adalah prinsip dasar organisasi tetapi juga menciptakan masalah-masalah komunikasi dimana hal ini cenderung memisahkan orangorang, bahkan bilang mereka saling berdekatan perbedaan fungsi, kepentingan dan istilah-istilah pekerjaan dapat membuat orangorang merasa bahwa mereka hidup dalam dunia yang berbeda. Akibatnya dapat menghalangi perasaan memasyarakat, membuat sulit memahami, dan mendorong terjadinya kesalahan-kesalahan.

\section{Pendekatan Komunikasi Organisasi}

Untuk melihat komunikasi yang terjadi dalam suatu organisasi dapat digunakan tiga pendekatan yaitu pendekatan makro, mikro dan individual,(Muhammad, 2014:74). Masing-masing dari pendekatan ini akan akan dijelaskan berikut ini:

1. Pendekatan Makro

Dalam pendekatan makro organisasi dipandang sebagai suatu struktur global yang berinteraksi dengan lingkungannya. Dalam berinteraksi ini organisasi melakukan aktivitas tertentu seperti memproses informasi dari lingkungan, mengadakan indentifikasi, melakukan integrasi dan menentukan tujuan organisasi dengan : Memproses Informasi dan Lingkungan; Identifikasi; Integrasi dengan Organisasi lain; Penentuan Tujuan.

2. Pendekatan Mikro

Pendekatan ini terutama memfokuskan kepada komunikasi dalam unit dan sub unit pada suatu organisasi. Komunikasi yang diperlukan pada tingkat ini adalah komunikasi antara anggota kelompok, komunikasi untuk pemberian orientasi dan latihan, komunikasi untuk melibatkan anggota kelompok dalam tugas kelompok, komunikasi untuk 
menjaga iklim organisasi, komunikasi dalam mensupervisi dan pengarahan pekerjaan dan komunikasi untuk mengetahui rasa kepuasan kerja dalam organisasi melalui : Orientasi dan Latihan; Keterlibatan Anggota; Penentuan Iklim Organisasi; Supervisi dan Pengarahan; Kepuasan Kerja.

3. Pendekatan Individual

Pendekatan individual berpusat kepada tingkah laku komunikasi individual dalam organisasi. Semua tugas-tugas yang telah diuraikan pada kedua pendekatan yang terdahulu akhirnya diselesaikan oleh komunikasi individual satu sama lainnya. Komunikasi individual ini ada beberapa bentuk diantaranya : Berbicara pada kelompok kerja; Menghindari dan berinteraksi dalam rapat-rapat; Menulis; Berdebat untuk suatu Usulan.

\section{Kerangka Pemikiran}

\begin{tabular}{|c|c|}
\hline \multicolumn{2}{|c|}{ Komunikasi Organisasi (X) } \\
\hline & $\begin{array}{l}\text { Kepercayaan antar } \\
\text { anggota }\end{array}$ \\
\hline & $\begin{array}{l}\text { Pembuatan keputusan } \\
\text { bersama }\end{array}$ \\
\hline & $\begin{array}{l}\text { Keterbukaan dalam } \\
\text { komunikasi kebawah }\end{array}$ \\
\hline & $\begin{array}{l}\text { Mendengarkan dalam } \\
\text { komunikasi keatas }\end{array}$ \\
\hline & $\begin{array}{l}\text { Perhatian terhadap tujuan- } \\
\text { tujuan kinerja tinggi }\end{array}$ \\
\hline
\end{tabular}

Sumber : Variabel (X) :Redding (1986). Variabel (Y) :Robbins (2001)

\section{Gambar 3. Kerangka Pemikiran}

\section{METODE PENELITIAN}

Dalam melaksanakan penelitian ini, penulis menggunakan metode deskriptif yaitu suatu metode yang berusaha mengumpulkan data yang sesuai dengan keadaan yang sebenarnya, menyajian serta menganalisa sehingga dapat memberikan gambaran yang cukup jelas atas objek yang diteliti dan kemudian dapat ditarik kesimpulan. Menurut Sugiyono (2012:11) metode penelitian deskriptif adalah metode penelitian yang bertujuan untuk menggambarkan, menjelaskan keadaan yang ada di perusahaan berdasarkan faktor dan data yang dikumpulkan kemudian disusun secara sistematis.

Berdasarkan latar belakang penelitian dan perumusan masalah penelitian serta berdasarkan teori yang telah diuraikan, penelitian ini tergolong ke dalam jenis penelitan deskriptif verifikatif. Penelitian ini termasuk dalam jenis penelitian verifikatif yang bertujuan untuk menguji hipotesis melalui validasi teori atau pengujian aplikasi teori. Penelitian ini bersifat kausal karena 
memiliki hubungan yang bersifat sebab akibat antara dua variabel atau lebih. Menurut Sugiyono (2012:11) Verifikatif adalah metode penelitian yang digunakan untuk mengetahui kebenaran hipotesis dengan menggunakan perhitungan statistik yang ditujukan untuk menjawab pertanyaan pada rumusan masalah sebagai berikut: Seberapa besar pengaruh komunikasi organisasi terhadap kepuasan kerja karyawan pada PD.BPR.LPK Garut Kota Cabang Bayongbong.

\section{Identifikasi Variabel}

Berdasarkan

kerangka pemikiran dan hipotesis yang telah disajikan sebelumnya, maka objek penelitian dapat dibedakan menjadi dua variabel, yaitu :

1. Variabel X / Variabel Bebas (Independent Variable), yaitu suatu variabel yang keberadannya tidak dipengaruhi oleh variabelvariabel lain, bahkan variabel inilah yang akan mempengaruhi variabel lain (Sugiyono, 2012:4). Dalam penelitian ini yang menjadi variabel bebas yakni Komunikasi Organisasi.

Dimensi yang digunakan adalah : Kepercayaan antar anggota; Pembuatan keputusan bersama; Keterbukaan dalam komunikasi ke bawah; Mendengarkan dalam komunikasi ke atas; Perhatian terhadap tujuan-tujuan kinerja tinggi.

2. Variabel Y / Variabel Terikat (Dependent Variable), yaitu suatu variabel yang keberadaanya dipengaruhi oleh variabelvariabel lain atau dipengaruhi oleh variabel bebas(Sugiyono,
2012:4). Dalam penelitian ini yang menjadi variabel terikat yaitu Kepuasan Kerja Karyawan. Dimensi yang digunakan adalah : Kerja yang menantang; Ganjaran yang pantas; Rekan sekerja; Kondisi kerja.

\section{Populasi}

Populasi adalah wilayah generalisasi yang terdiri atas: obyek/subyek yang mempunyai kualitas dan karakteristik tertentu yang ditetapkan oleh peneliti untuk dipelajari dan kemudian ditarik kesimpulannya (Sugiyono, 2012:61).

Populasi penelitian ini adalah seluruh karyawan pada PD.BPR.LPK Garut Kota Cabang Bayongbong.Objek penelitian terdiri dari 36 orang.

\section{Sampel}

Sampel adalah bagian dari jumlah dan karakteristik yang dimiliki oleh populasi (Sugiyono, 2012:62). Menurut Riduwan (2004:56) Sampel adalah bagian dari populasi yang mempunyai ciri-ciri atau keadaan tertentu yang akan diteliti.

Metode yang digunakan untuk menentukan sampel dalam penelitian ini adalah

Sampling jenuh dimana pemilihan sampel berdasarkan seluruh anggota populasi. Istilah lain sampling jenuh adalah sensus, dimana semua anggota populasi dijadikan sampel.(Sugiyono, 2012:78).

\section{Uji Validitas}

Instrumen yang valid berarti alat ukur yang digunakan untuk mendapatkan data (mengukur) itu valid. Valid berarti instrument tersebut dapat digunakan untuk 
mengukur apa yang hendak diukur (Sugiyono, 2012:348). Sehingga, dapat dikatakan semakin tinggi validitas suatu alat test maka alat tersebut makin mengenai sasarannya atau semakin menunjukan apa yang seharusnya di ukur.Dalam penelitian ini pengujian validitas yang digunakan penulis adalah dengan menghitung korelasi antara skor masing-masing butir pertanyaan dan total skor konstruk. Pengujian dilakukan dengan menggunakan statistical program for society science (SPSS).

Jika $r$ hitung untuk tiap $r$ butir pertanyaan bernilai positif dan lebih besar dari $r$ tabel maka butir pertanyaan tersebut dikatakan valid (Sunyoto, 2009:72-73). Untuk menentukan kevalidan dari item kuesioner digunakan metode korelasi Product Moment yaitu dengan mengkorelasikan skor total yang dihasilkan oleh masing-masing responden dengan skor masingmasing item dengan rumus sebagai berikut:

Dasar pengambilan keputusan :

- Jika $r$ positif, serta $r \geq 0.30$ maka item pertanyaan tersebut valid.

- Jika $r$ negatif, serta $r<0.30$ maka item pertanyaan tersebut tidak valid.

\section{Uji Reliabilitas}

Keandalan (reliability) salah satu pengukuran sejauh mana pengukuran tersebut tanpa bias (bebas kesalahan-error free) dan aren itu menjamin pengukuran yang konsisten lintas waktu dan lintas program item dalam instrumen. Dengan kata lain, keandalan suatu pengukuran merupakan suatu indikasi mengenai stabilitas dan konsistensi dimana instrument mengukur konsep dan membantu menilai "ketepatan" sebuah pengukuran (Sekaran, 2007:40).

Penelitian ini menggunakan metode one shot. Pengukuran keandalan butir pertanyaan dengan sekali menyebarkan kuesioner pada responden, kemudian hasil skornya diukur korelasinya antar skor jawaban pada butir pertanyaan yang sama dengan bantuan computer SPSS, dengan fasilitas Alpha Cronbach(a). suatu konstruk atau variabel dikatakan reliable jika memberikan alpha cronbach besar dari 0,60 (Sunyoto, 2009:67-68).

Untuk menguji reliabilitas dalam pengukuran ini, penulis menggunakan koefisien reliabilitas Alpha Cronbach, yaitu dengan rumusan sebagai berikut:

$$
\alpha=\left[\frac{k}{k-1}\right]\left[1-\frac{\sum S_{i}^{2}}{S_{x}{ }^{2}}\right]
$$

Ket : $\mathrm{k}$ : Jumlah instrument pertanyaan

$$
\sum S_{i}{ }^{2} \text { : Jumlah varians dari }
$$
tiap instrument pertanyaan

$S_{x}{ }^{2}$ : Varians dari keseluruhan instrument pertanyaan

\section{Teknik Analisis Data}

\section{Analisis Regresi Linier Sederhana}

Analilsis yang digunakan dalam penelitian ini adalah model analisis regresi linier sederhana. Analisis regresi digunakan untuk mengukur pengaruh variabel independen (X) terhadap variabel dependen (Y). Analisis linier sederhana adalah pengukuran pengaruh antar variabel yang hanya 
melibatkan satu variabel independen (X).

Dikatakan linier karena setiap estimasi atas nilai yang diharapkan mengalami peningkatan atau penurunan mengikuti garis lurus (Sunyoto, 2009:9).

Manfaat dari hasil analisis regresi adalah untuk membuat keputusan apakah naik dan menurunnya variabel independen dapat dilakukan melalui peningkatan variabel independen atau tidak (Sugiyono, 2012:260).

Bentuk persamaan regresi berupa : $\hat{\mathbf{Y}}=\mathbf{a}+\mathbf{b} . \mathbf{X}$

Ket : $\quad \hat{Y}=$ Subyek dalam variabel dependen yagn diprediksikan

$\mathrm{a}=$ Harga Y ketika harga $\mathrm{X}=0$ (Konstanta)

$\mathrm{b}=$ Koefisien regresi

$\mathrm{X}=$ Subyek pada variabel independen yang mempunyai nilai tertentu

\section{Statistik Deskriptif}

Statistik deskriptif adalah statistik yang berfungsi untuk mendeskripsikan atau memberi gambaran terhadap obyek yang diteliti melalui data sampel atau populasi sebagaimana adanya, tanpa melakukan analisis dan membuat kesimpulan yang berlaku untuk umum (Sugiyono, 2012:29).

\section{Metode Transformasi Data}

Mentransformasikan data ordinal menjadi data interval gunanya untuk memenuhi sebagian dari syarat analisis parametrik yang mana data setidak-tidaknya berskala interval. Teknik transformasi yang paling sederhana dengan menggunakan Method of Succesive Interval (MSI) (Riduwan dan Engkos Achmad Kuncoro, 2008:30).
Langkah-langkah

transformasi data ordinal ke interval sebagai berikut:

1) Pertama perhatikan setiap butir jawaban responden dari angket yang disebarkan.

2) Pada setiap butir ditentukan berapa orang yang mendapat skor 1, 2, 3, 4 dan 5 yang disebut dengan frekuensi.

3) Setiap frekuensi dibagi dengan banyaknya responden dan hasilnya disebut proporsi.

4) Tentukan nilai proporsi kumulatif dengan jalan menjumlahkan nilai proporsi secara berurutan perkolom skor.

5) Gunakan tabel Distribusi Normal, hitung nilai $\mathrm{Z}$ untuk setiap proporsi kumulatif yang diperoleh.

6) Tentukan nilai tinggi densitas untuk setiap nilai $\mathrm{Z}$ yang diperoleh (dengan menggunakan tabel Tinggi Densitas).

7) Tentukan nilai skala dengan menggunakan rumus:

NS

$=\frac{(\text { Densityatlowerlimit })-(\text { Densityatupperlimit })}{(\text { Areaunderupperlimit }- \text { Areaunderlowerlimit })}$

8) Nilai Skala yang terkecil (harga negatif yang terbesar) diubah menjadi satu.

\section{ANALISIS DATA DAN PEMBAHASAN}

Uji Validitas dan Reliabilitas Item Variabel Komunikasi Organisasi

Pengujian validitas menggunakan korelasi product moment (indeks validitas) dimana butir pernyataan dinyatakan valid jika koefisien korelasi butir pernyataan $\geq 0,30$. Kemudian pengujian reliabilitas menggunakan metode alpha-cronbach dan hasilnya dinyatakan reliabel jika koefisien 
reliabilitas lebih besar dari 0,60. Berikut rangkuman hasil pengujian validitas dan reliabilitas masingmasing kuesiner penelitian.

Dari rekapitulasi hasil pengujian validitas dan reliabilitas instrumen untuk variabel komunikasi oraganisasi terlihat bahwa seluruh pernyataan yang diajukan memiliki koefisien validitas di atas titik kritis 0,300 . Hal ini menunjukan bahwa seluruh pernyataan yang diajukan tersebut sudah melakukan fungsi ukurnya. Dan dari hasil pengujian reliabilitas instrumen, diperoleh nilai koefisien alpha sebesar 0,886 . Nilai ini lebih besar dari 0,600 yang menunjukan bahwa variabel komunikasi organisasi sudah menunjukan keandalannya.

Uji Validitas dan Reliabilitas Item Variabel Kepuasan Kerja Karyawan

Pengujian validitas

menggunakan korelasi product moment (indeks validitas) dimana butir pernyataan dinyatakan valid jika koefisien korelasi butir pernyataan $\geq 0,30$. Kemudian pengujian reliabilitas menggunakan metode alpha-cronbach dan hasilnya dinyatakan reliabel jika koefisien reliabilitas lebih besar dari 0,60. Berikut rangkuman hasil pengujian validitas dan reliabilitas masingmasing kuesiner penelitian.
Dari rekapitulasi hasil pengujian validitas dan reliabilitas instrumen untuk variabel kepuasan kerja karyawan terlihat bahwa seluruh pernyataan yang diajukan memiliki koefisien validitas di atas titik kritis 0,300 . Hal ini menunjukan bahwa seluruh pernyataan yang diajukan tersebut sudah melakukan fungsi ukurnya. Dan dari hasil pengujian reliabilitas instrumen, diperoleh nilai koefisien alpha sebesar 0,844. Nilai ini lebih besar dari 0,600 yang menunjukan bahwa variabel kepuasan kerja karyawan sudah menunjukan keandalannya.

\section{Uji Normalitas Data}

Uji normalitas data digunakan untuk mengetahui apakah data yang digunakan berdistribusi secara normal atau tidak. Model regresi yang baik adalah model yang berdistribusi normal atau mendekati normal. Untuk mengetahui bagaimana distribusi kenormalan data, digunakan uji kolmogorv smirnov dengan dasar pengambilan keputusan sebagai berikut:

a. Jika probabilitas $\geq 0,05$ maka distribusi dari populasi adalah normal.

b. Jika probabilitas $<0,05$ maka populasi tidak berdistribusi secara normal.

Tabel 2. Hasil Uji Normalitas Data 
One-Sanple Kolmogorov-Smirnov Test

\begin{tabular}{|ll|r|r|}
\hline & & \multicolumn{1}{|c|}{$\begin{array}{c}\text { Komunikasi } \\
\text { Organisasi }\end{array}$} & $\begin{array}{c}\text { Kepuasan } \\
\text { Kerja }\end{array}$ \\
\hline N & Mean & 36 & 36 \\
Normal Parameters ${ }^{\text {ab }}$ & Std. Deviation & 45,0828 & 23,4270 \\
Most Extreme Differences & Absolute & 6,85799 & 3,57500 \\
& Positive &, 078 &, 115 \\
& Negative &, 059 &, 102 \\
Kolmogorov-Smimov Z & &,- 078 &,- 115 \\
Asymp. Sig. (2-tailed) & &, 466 &, 692 \\
\hline
\end{tabular}

a. Test distribution is Normal.

b. Calculated from data.

Dari hasil pengujian di atas terlihat bahwa nilai signifikansi yang diperoleh kedua variabel masing-masing sebesar 0,981 dan 0,724. Kedua nilai ini berada di atas 0,05 yang menunjukan bahwa kedua variabel yang diuji berdistribusi secara normal, dengan kata lain asumsi normalitas data terpenuhi.

\section{Persamaan Regresi Linier Sederhana \\ Persamaan regresi linier} sederhana yang akan dibentuk adalah : $\mathrm{Y}=\mathrm{a}+\mathrm{bX}$

Dimana : $\mathrm{Y}=$ nilai taksiran untuk kepuasan kerja karyawan; a = konstanta

$\mathrm{X}=$ komunikasi organisasi.

Tabel 3. Persamaan Regresi Linier Sederhana

Coefficients $^{2}$

\begin{tabular}{|c|c|c|c|c|c|c|}
\hline \multirow[b]{2}{*}{ Model } & & \multicolumn{2}{|c|}{ Unstandardized Coefficients } & \multirow{2}{*}{$\begin{array}{r}\begin{array}{r}\text { Standardized } \\
\text { Coefficients }\end{array} \\
\text { Beta } \\
\end{array}$} & \multirow[b]{2}{*}{$\mathrm{t}$} & \multirow[b]{2}{*}{ Sig. } \\
\hline & & $\mathrm{B}$ & Std. Error & & & \\
\hline 1 & (Constant) & 10,836 & 3,441 & & 3,149 &, 003 \\
\hline & Komunikasi Organisasi & 279 &, 075 &, 536 & 3,700 &, 001 \\
\hline
\end{tabular}

a. Dependent Variable: Kepuasan Kerja

Berdasarkan tabel di atas, diperoleh persamaan regresi linier sederhana sebagai berikut : $\mathrm{Y}=10,836+0,279$ $\mathrm{a}=10,836$

Artinya

ketika komunikasi organisasi bernilai nol (0) dan tidak ada perubahan, maka kepuasan kerja karyawan akan bernilai sebesar 10,836.

$\mathrm{b}=0,279$ ketika komunikasi organisasi mengalami peningkatan, maka kepuasan kerja karyawan

akan meningkat sebesar 0,279 .

\section{Analisis Korelasi}

Analisis korelasi digunakan untuk melihat kekuatan asosiasi (hubungan) yang terjadi antara variabel bebas dengan variabel terikat. Dalam hal ini untuk melihat tingkat keeratan antara komunikasi organisasi dengan kepuasan kerja karyawan. Adapun teknik analisis data yang digunakan dalam penelitian ini menggunakan 
analisis korelasi pearson product moment karena data yang digunakan telah ditransformasi menjadi skala interval.
Dari pengolahan data yang telah dilakukan, diperoleh hasil sebagai berikut:

Tabel 4. Hasil Analisis Korelasi Pearson

Correlations

\begin{tabular}{|ll|r|r|}
\hline & Komunikasi & \multicolumn{2}{c|}{$\begin{array}{c}\text { Kepuasan } \\
\text { Kerja }\end{array}$} \\
\hline Komunikasi Organisasi & Pearson Correlation & 1 &, 536 \\
& Sig. (2-tailed) & 36 &, 001 \\
& $\mathrm{~N}$ & 36 & 36 \\
\hline Kepuasan Kerja & Pearson Correlation &, 536 & 1 \\
& Sig. (2-tailed) &, 001 & 36 \\
& $\mathrm{~N}$ & 36 & \\
\end{tabular}

Berdasarkan tabel di atas, terlihat bahwa nilai koefisien korelasi yang diperoleh antara komunikasi organisasi dengan kepuasan kerja karyawan adalah sebesar 0,536. Nilai korelasi bertanda positif yang menunjukan bahwa hubungan yang terjadi antara keduanya adalah searah. Dimana semakin kuat komunikasi organisasi, maka akan diikuti pula oleh semakin tingginya kepuasan kerja karyawan. Berdasarkan interpretasi koefisien korelasi, nilai korelasi sebesar 0,536 termasuk kedalam kategori hubungan yang sedang, berada dalam kelas interval antara 0,400 0,599 .

\section{Koefisien Determinasi}

Koefisien determinasi (KD) merupakan kuadrat dari nilai $\mathrm{R}$ atau korelasi. Koefisien determinasi digunakan untuk mengetahui kontribusi pengaruh yang diberikan variabel bebas terhadap variabel terikat. Dari pengolahan data yang telah dilakukan, diperoleh hasil sebagai berikut:

Tabel 5.Hasil Koefisien Determinasi

\begin{tabular}{|l|c|c|c|c|}
\hline Model & R & RSquare & $\begin{array}{c}\text { Adjusted } R \\
\text { Square }\end{array}$ & $\begin{array}{c}\text { Std. Error of } \\
\text { the Estimate }\end{array}$ \\
\hline 1 &, $536^{2}$ &, 287 &, 266 & 3,06265 \\
\hline
\end{tabular}

Berdasarkan tabel output di atas, terlihat bahwa nilai korelasi (R) yang diperoleh sebesar 0,536, dengan demikian koefisien determinasi dapat dihitung sebagai berikut:

$\mathrm{KD}=\mathrm{r}^{2} \times 100 \%=(0,536)^{2} \times 100 \%$ $=28,7 \%$
Dengan demikian maka dapat disimpulkan bahwa komunikasi organisasi memberikan kontribusi pengaruh terhadap kepuasan kerja karyawan PD BPR LPK Garut Kota Cabang Bayongbong sebesar 28,7\%, sedangkan sisanya sebesar $71,3 \%$ 
merupakan kontribusi dari faktor lain yang tidak diteliti.

\section{Pengujian Hipotesis}

Untuk membuktikan apakah komunikasi organisasi berpengaruh signifikan terhadap kepuasan kerja karyawan, maka dilakukan pengujian hipotesis dengan rumusan hipotesis sebagai berikut:

$\mathrm{H}_{0}: \beta<0$ artinya, komunikasi organisasi tidak berpengaruh positif dan signifikan terhadap kepuasan kerja karyawan PD BPR LPK
Garut Kota Cabang Bayongbong.

$\mathrm{H}_{\mathrm{a}}: \beta \geq 0$ artinya, komunikasi organisasi berpengaruh positif dan signifikan terhadap kepuasan kerja karyawan PD BPR LPK Garut Kota Cabang Bayongbong.

Taraf signifikansi $(\alpha): 0,05(5 \%)$

Kriteria uji : tolak $\mathrm{H}_{0}$ jika nilai t-hitung $>\mathrm{t}$-tabel, terima $\mathrm{H}_{\mathrm{a}}$ jika nilai t-hitung $<\mathrm{t}$-tabel

Nilai statistik uji t dapat diketahui dari tabel output berikut:

Tabel 6.Pengujian Hipotesis

Coefficients $^{2}$

\begin{tabular}{|c|c|c|c|c|c|c|}
\hline \multirow{2}{*}{\multicolumn{2}{|c|}{ Model }} & \multicolumn{2}{|c|}{ Unstandardized Coefficients } & \multirow{2}{*}{$\begin{array}{c}\begin{array}{r}\text { Standardized } \\
\text { Coefficients }\end{array} \\
\text { Beta } \\
\end{array}$} & \multirow[b]{2}{*}{$t$} & \multirow[b]{2}{*}{ Sig. } \\
\hline & & $\mathrm{B}$ & Std. Error & & & \\
\hline & (Constant) & 10,836 & 3,441 & & 3,149 &, 003 \\
\hline & Komunikasi Organisasi &, 279 &, 075 &, 536 & 3,700 &, 001 \\
\hline
\end{tabular}

a. Dependent Variable: Kepuas an Kerja

Berdasarkan tabel di atas, diperoleh informasi bahwa nilai $t$-hitung yang diperoleh variabel komunikasi organisasi sebesar 3,700. Nilai ini akan dibandingkan dengan nilai $\mathrm{t}_{\text {-tabel }}$ pada tabel distribusi t. Dengan $\alpha=0,05, \mathrm{df}=$ $\mathrm{n}-\mathrm{k}-1=36-1-1=34$, diperoleh nilai $\mathrm{t}-$ tabel untuk pengujian satu pihak sebesar 1,691. Dari nilai-nilai di atas terlihat bahwa nilai t-hitung yang diperoleh 3,700 $>\mathrm{t}_{\text {-tabel }}$ 1,691. Sesuai dengan kriteria pengujian hipotesis bahwa $\mathrm{H}_{0}$ ditolak dan $\mathrm{H}_{\mathrm{a}}$ diterima. Artinya komunikasi organisasi berpengaruh positif dan signifikan terhadap kepuasan kerja karyawan PD BPR LPK Garut Kota Cabang Bayongbong.

\section{SIMPULAN DAN SARAN}

Komunikasi organisasi di PD BPR LPK Garut Kota Cabang Bayongbong termasuk kedalam kategori tinggi . Hal itu dapat dilihat dari semua lima indikator variabel komunikasi organisasi yaitu Kepercayaan antar anggota,Pembuatan keputusan bersama,Keterbukaan dalam komunikasi ke bawah,Mendengarkan dalam komunikasi ke atas, Perhatian terhadap tujuan-tujuan kinerja tinggi. Dari lima indikator tersebut sudah mendukung dan berjalan dengan baik. Adapun item yang dipersepsikan karyawan dengan nilai terendah yaitu pada item dilibatkan oleh pemimpin untuk membuat sebuah keputusan ketika berada dalam rapat pada indikator pembuatan keputusan bersama.

Para karyawan di PD BPR LPK Garut Kota Cabang Bayongbong memiliki kepuasan kerja yang tinggi. Kontribusi 
tertinggi terletak pada item pekerjaan diselesaikan tepat waktu dalam indikator kerja yang menantang . Seluruh indikator kepuasan kerja lainnya juga berkontribusi tinggi. Adapun indikator yang memiliki skor nilai terendah dibandingkan dengan indikator-indikator lainnya yaitu indikator gaji dan keuntungan pada item intensif atau bonus yang sesuai.

Komunikasi organisasi berpengaruh positif dan signifikan terhadap kepuasan kerja karyawan PD PD BPR LPK Garut Kota Cabang Bayongbong dengan kontribusi pengaruh yang diberikan sebesar 28,7\%, sedangkan sisanya sebesar $71,3 \%$ merupakan kontribusi dari faktor lain yang tidak diteliti, Berdasarkan kajian teoritis, variabel lain diluar variabel yang diteliti yang mempengaruhi kepuasan kerja adalah: kinerja karyawan, Motivasi, kompensasi, efektivitas kepemimpinan, budaya organisasi, dan stress kerja.

Indikator komunikasi organisasi yang berorientasikan pada pembuatan keputusan bersama merupakan indikator yang memiliki skor terendah dibandingkan dengan indikator lain. Maka dari itu untuk pengembangan selanjutnya, indikator pembuatan keputusan bersama ini,khususnya mengenai dilibatkan oleh pempimpin untuk membuat sebuah keputusan ketika berada dalam rapat ini perlu diperkuat lagi, sehingga karyawan mampu bekerjasama dengan baik antar karyawan dalam pembuatan keputusan bersama ataupun dengan bagian lain, dan karyawan diharuskan memiliki gaya tersendiri yang tinggi apabila memberikan suatu keputusan setiap diberikan kesempatan dalam hal tersebut. Adapun dari empat indikator lainnya yang memiliki skor yang tinggi perlu dipertahankan dan ditingkatkan.

Item intensif atau bonus yang sesuai pada Indikator gaji dan keuntungan dalam variabel kepuasan kerja memiliki skor terendah dibandingkan dengan indikator lain,hal ini mengindikasikan bahwa indikator dari gaji dan keuntungan kurang berjalan lancar sehingga terjadinya salah satu masalah ketidakpuasan kerja karyawan. Untuk meningkatkan kepuasan kerja karyawan dalam indikator gaji dan keuntungan harus sebanding dengan beban kerja karyawan, dengan tercapainya kepuasan kerja maka produktifitas dan kinerja karyawan akan meningkat dan tujuan perusahaan berjalan lancar dengan baik. Adapun indikator lainnya yang memiliki skor yang tinggi perlu dipertahankan dan ditingkatkan guna pencapaian tujuan dengan efektif dan efisien.

Disarankan kepada peneliti lainya untuk melakukan penelitian lanjutan berkaitan dengan pengaruh komunikasi organisasi terhadap kepuasan kerja di PD BPR LPK Garut Kota Cabang Bayongbong dengan aspek-aspek yang lain seperti kinerja karyawan terhadap kepuasan kerja sehingga dapat ditingkatkan mengingat pada penelitian ini terdapat pengaruh yang kuat dan searah antara komunikasi organisasi terhadap kepuasan kerja.

\section{DAFTAR PUSTAKA}

Achmad Kuncoro, Engkos dan Riduwan, (2008). Cara Menggunakan dan Memaknai Analisis Jalur (Path Analysis). Bandung: Alfabeta.

Alfajar,Muhammad Rasyad. 2014. Analisis kinerja keuangan bank syariah devisadan bank syariah non devisa dengan metode 
RGEC. Jurnal mahasiswaUIN Sunan Kalijaga.

As'ad, 2003, Kepemimpinan Efektif DalamPerusahaan.Ed.2.Liberty.Y ogyakarta.

Danang Sunyoto, 2009, "Analisis Regresi dan Uji Hipotesis", MedPress, Yogyakarta.

Danang Sunyoto.2013.Metodologi Penelitian Akuntansi. Bandung: PT Refika Aditama Anggota Ikapi.

Luthans, Fred. 2006.Perilaku Organisasi, (Alih Bahasa V.A Yuwono, dkk),Edisi Bahasa Indonesia, Yogyakarta: ANDI.

Malayu, S.P. Hasibuan 2007. Manajemen Sumber Daya Manusia, cetakankesembilan, Jakarta : PT Bumi Aksara.

Pratminingsih, Sri Astuti. (2006).Komunikasi Bisnis (Edisi pertama). Yogyakarta :Graha Ilmu.

Stephen Robbins, 2001, "Perilaku Organisasi“, Jilid 1 Edisi 8, PT Prenhalindo, Jakarta.

Sugiyono. 2012. Metode Penelitian Pendidikan (Pendekatan Kuantitatif, Kualitatif, dan R\&D).Bandung : Alfabeta.

Uma Sekaran. 2009. Research Methods For Business(Metodologi Penelitian untuk Bisnis). Jakarta: Salemba Empat. 